\title{
SOCIAL WORK AND ENVIRONMENTALly INDUCED DisPlaCEMENT: A COMMENTARY
}

\author{
Julie Drolet, \\ With CONTRIBUTIONS FROM TifFany SAMPSON, \\ Deborah Prashanthi Jebaraj, and Laura Richard
}

\begin{abstract}
Environmentally induced displacement is a growing concern across the globe. The human and social dimensions of affected displaced and migrating populations are of concern to the profession of social work, as many social workers are directly involved in working with vulnerable populations affected by environmental changes due to climate change, disasters, and environmental degradation. This new reality presents challenges in addressing social and economic inequalities and disparities, and this commentary argues for a need to build capacity among practitioners to consider the interconnections of social, economic, and environmental challenges in bridging practice and policy in ongoing legal discourses.

\section{Résumé}

Les déplacements provoqués par l'environnement sont une préoccupation internationale croissante. Les effets de nature humaine et sociale sur les déplacés et les populations migrantes préoccupent les professionnels du travail social, étant donné que de nombreux travailleurs sociaux se trouvent impliqués auprès de populations vulnérables affectées par des changements environnementaux dus aux changements climatiques, à la dégradation et aux désastres environnementaux. Cette nouvelle réalité pose des défis puisqu'elle relève les inégalités et disparités sociales et économiques. Cet article met donc en lumière le besoin de construire chez les travailleurs sociaux la capacité de considérer les interactions entre les défis sociaux, économiques, et environnementaux lorsqu'ils mettent en lien des pratiques et des politiques en matière légale.
\end{abstract}

\section{Introduction}

Social workers around the world play a potentially important role in promoting sustainable social development by bringing together social, economic, and environment considerations in local communities. The Global Agenda for Social Work and Social Development is designed by the International Federation of Social Workers (IFSW), International Association of Schools of Social Work (IASSW), and International Council on Social Welfare (ICSW) to strengthen the profile of social work in order to enable social workers to make a stronger contribution to policy development. ${ }^{1}$ The Global Agenda focuses on four priority areas: (1) promoting social and economic equalities, (2) promoting the dignity and worth of peoples, (3) working toward environmental sustainability, and (4) strengthening recognition of the importance of human relationships. Human activities in most parts of the world are transforming the global environment. ${ }^{2}$ A number of factors contribute to global environmental change such as air pollution and ozone depletion, climate change, land use change, deforestation, desertification, loss of biodiversity, land degradation, fresh water availability, hazardous wastes, and war. ${ }^{3}$ Increasingly, social workers are being called upon to promote community capacity-building in response to social, economic, and environmental challenges that lead to displacement and migration due to these factors. ${ }^{4}$ However, there is a need to build capacity in order to develop sustainable and effective interventions. "Green social work" is a term used to describe a holistic understanding of various environments and their impacts upon people's behaviour. ${ }^{5}$ The human and social dimensions are central in addressing vulnerabilities, as people's health and well-being suffer as a result of inequalities, poverty, and unsustainable 
environments related to the impacts of climate change, pollutants, war, natural disasters, and violence, to which there are inadequate international responses. ${ }^{6}$ This article provides a commentary on the need to build social work's capacity in the international arena in order to contribute to the political and legal discourses on environmentally induced displacement. To meet this emerging need, the field of social work will need to strengthen its capacity in community development, advocacy, and anti-oppressive social protection initiatives, rather than clinical individualized social work interventions, in order to create interventions that bridge the needs of affected populations and policy development.

Definitions of Environment-Induced Displacement Lonergan ${ }^{7}$ explains that environmentally induced population movements are caused by (1) environmental stress such as an earthquake, cyclone, or other natural disaster; (2) development projects that create a permanent change in habitat, thus forcing people to leave their homes; (3) cumulative changes or "slow-onset" changes such as deforestation; (4) industrial accidents such as the nuclear accident at Chernobyl; and (5) conflict and warfare where environmental degradation is both a cause and effect of armed conflict. The term "development-induced displacement" concerns the plight of millions of people in developing countries who have been compelled or persuaded to move from their residences and their environments and have been uprooted from their livelihoods as a result of disruptions caused by infrastructural projects that characterized development planning in the 1960s and 1970 s. $^{8}$ It is estimated that 15 million migrants are displaced by development projects every year in the world. ${ }^{9}$ The question of how to protect people who are displaced from their homes and livelihoods by development projects, and the rights and responsibilities of various stakeholders, has led many to consider how affected populations may share equitably in the benefits. ${ }^{10}$ Assan and Rosenfeld discuss the absence of a recognized definition, the disagreement over the number of environmental migrants, and the diverse legal perspectives. ${ }^{11}$ McAdam considers climate change, forced migration, and international law by questioning whether flight from habitat destruction should be viewed as another facet of traditional international protection or as a new challenge requiring more creative and policy responses. ${ }^{12}$ "Environmental refugees" under international law are not refugees and not entitled to legal protection when in a host state. ${ }^{13}$ There is a need to facilitate policy efforts towards addressing diverse forms of migration at the national and international levels. The concept of environmental migration is controversial, largely because of the difficulty in measuring the extent to which environmental factors compel people to move. ${ }^{14}$ "Environmentally induced migrants" is a term used to describe persons on the move in response to immediate life-threatening events or because the environment has deteriorated their livelihoods so much that they can no longer support themselves. ${ }^{15}$ Betts develops the concept of "survival migration" to highlight the situation of people whose own countries are unable or unwilling to ensure their most fundamental human rights (yet fall outside the framework of the refugee protection regime) by not focusing on the underlying cause of movementwhether persecution, conflict, or environment. ${ }^{16}$

Research examining the nexus between environmental change and human mobility has focused primarily on the migration of individuals and households. ${ }^{17}$ Climate change is predicted to dislocate millions of people in regions already vulnerable to economic, political, and environmental disruption. ${ }^{18}$ Adger considers aspects of fairness, justice, and equity in adaptation responses for vulnerable groups. ${ }^{19}$ More recently, there is an emerging literature that considers how some communities are under direct threat of displacement due to climate-related factors. Corlett examines the effects of climate change as experienced by the people of Tuvalu, a tiny, picturesque Pacific nation. ${ }^{20}$ Bronen discusses how the spectre of millions of people fleeing their homes because of climate change has sparked an international debate about creating human rights protections for climate change, and specifically presents the crisis in the Arctic where traditional responses of hazard prevention and disaster relief are no longer protecting communities, and have resulted in climate-induced relocation or "community relocation" as the only feasible solution to permanently protect the inhabitants of these communities. ${ }^{21}$ The relocation of entire communities, not just individuals and households, may, in some circumstances, be the best adaptation response to climate change. ${ }^{22}$ This new evidence demonstrates that flight is caused by environmental changes rather than the longstanding view that environmental migrants leave their homes in response to a number of social, economic, and environmental factors.

Despite the root causes of movement, the impact of environmentally induced migration on sustainable development and the achievement of the Millennium Development Goals is an emerging and relatively unexplored issue. ${ }^{23}$ The natural environment can lead to population movement in two main ways: through natural hazards such as earthquakes, tsunamis, wildfires, and other natural disasters that suddenly force people to move, and through slow-onset environmental changes such as soil degradation and erosion, deforestation, desertification, water, soil and air pollution, water-logging and salinization of irrigated lands, landslides and mudslides, radiation from nuclear waste, saltwater 
intrusion and accelerated coastal erosion, riverbank erosion, extreme aridity and irregular rainfall, and sea-level rise. The interrelationship between the environment and other social, political, and economic factors, especially poverty and security, renders legal definitions and understandings complex for humanitarian efforts, disaster recovery, and development strategies. An integrated and holistic approach is necessary in considering environmentally induced displacement and migration movements and decisions, in which environmental factors should be considered in connection with other socio-economic factors. There is a need for further research to draw lessons for the future and to understand more clearly the policy implications of environmentally induced displacement and migration.

According to Warner, Hamza, Oliver-Smith, Renaud, and Julca, the reasons to migrate are not simple but rather involve influences that "push" and "pull" people to leave their home, which include economic, social, political, and environmental aspects. These factors are often interconnected, making it difficult to determine "one from the other." 24 With knowledge in micro, mezzo, and macro systems, social workers have the skills to examine complex social issues as they relate to humans and their environment. Knowing that migration does not occur in isolation from one's social environment, it is critical to examine who is migrating and who is not migrating, particularly in situations of environmentally induced displacement, in order to understand intersections of individuals, families, and communities with respect to power, discrimination, and vulnerability.

\section{Climate Change and Natural Hazards}

There is growing recognition that the effects of climate change are likely to lead to more migration, both internally and internationally, in the relatively near future. ${ }^{25}$ Official estimates put the future scale of human displacement as a result of climate change from 150 million to one billion people. ${ }^{26}$ Migration, whether permanent or temporary, internal or international, has always been a possible coping strategy for people facing environmental changes. ${ }^{27}$ Yet migration caused by human-induced climate change as an adaptation strategy is a relatively new phenomenon. In 1990 the Intergovernmental Panel on Climate Change noted that the greatest single impact of climate change might be on human migration-with millions of people displaced by shoreline erosion, coastal flooding, and agricultural disruption. ${ }^{28}$ Climate-related human migration is as old as the constant onslaught of droughts, floods, food shortages, and other climate-related changes on earth that have forced the resettlement of populations throughout history. ${ }^{29}$ In the World Disasters Report (2012) on forced migration and displacement, the International Federation of Red Cross and Red Crescent Societies explains that people's vulnerability to environmental hazards is increasing due to longterm degradation that is an effect of climate change. ${ }^{30}$ Environmentally induced displacement and migration has the potential to become a phenomenon of a scale and scope never experienced. Its effects on the global economy, international development, and national budgets could have significant implications for almost all dimensions of human, political, and state security.

Climate change and its impact on migration is the object of increasing attention for both policy-makers and researchers. ${ }^{31}$ There is a need for international legal and policy frameworks to consider environmental and climatic factors in migration-and their relationship to other social, political, or economic aspects, given the context of migration-and the manner in which to treat the people who move because of environmental factors. ${ }^{32}$

Climate change mitigation and adaptation strategies are both required to address this global challenge resulting from increasing global temperatures due to greenhouse gases. Migration can be considered an adaptation mechanism for those willing and able to move away from increased risk and dangerous circumstances. In other extreme situations, those with fewer means to move may opt to migrate as an expression of failed adaptation to the impacts of climate change in order to survive at a basic level. Given the complexity in determining causality of migration within the broader context of social, economic, and environmental factors affecting population movements, the International Organization for Migration defines the term environmental migrants as "persons or groups of persons who, for compelling reasons of sudden or progressive change in the environment that adversely affects their lives or living conditions, are obliged to leave their habitual homes, or choose to do so, either temporarily or permanently, and who move either within their country or abroad." 33 Facing severe environmental degradation due to climate change, populations can mitigate and/or adapt to the effects, accept a lower quality of life, or leave the affected areas. ${ }^{34}$

\section{The Potential Role of Social Work}

Social work's involvement in shaping the discussion on and response to the growing issue of environmentally induced displacement is critical. ${ }^{35}$ Though the reality of displacement due to environmental factors is not a new one, the rate at which this kind of displacement is occurring and will occur is unprecedented. While it is difficult to predict the numbers of displaced persons, in part due to the lack of consensus regarding definitions and terminology, what is indisputable is that the number of environmentally 
displaced persons will continue to increase. To date, much of the literature on issues related to environmentally induced displacement has been focused on physical and ecological impacts and legal ramifications, while the human and social dimensions have been touched on only briefly or omitted entirely. Dominelli argues that many of these social costs are invisible, downplayed by economic balance sheets that fail to include the impact of industrialization and loss of environmental amenities on people, livelihoods, homes, land, and ancestral belonging associated with a sense of place. ${ }^{36}$ Individuals, families, and whole communities suffer trauma and loss due to displacement. ${ }^{37}$ Livelihoods deteriorate due to changing climatic conditions and land degradation over time. ${ }^{38}$ When livelihoods are disrupted, cultural customs are threatened, basic human needs often go unmet, and human rights are seriously compromised as a result of being displaced. ${ }^{39}$ The communities to which displaced persons migrate are affected as well. In migrantreceiving countries, many displaced migrants are traumatized, vulnerable, exploited, and overwhelmed by the problems of coping with radical legal, economic, social, cultural, and personal problems for which they are inadequately prepared, financed, and socially supported. ${ }^{40}$ The settlement and integration needs of immigrants and newcomers are well known in the literature, and there is a need to better understand the challenges and opportunities to provide migrants with the same level of support services to facilitate a "welcoming community" in the receiving local community. Adaptive social protection initiatives in developing countries are supporting climate change adaptation and mitigation in diverse contexts. ${ }^{41}$

Increasingly, social work practitioners, academic researchers, and community members are playing a role in addressing a variety of issues resulting from environmentally induced displacement and migration. This can include accompanying affected individuals, families, and communities in their quest for land use and property rights, providing social welfare, housing, employment, decent living conditions, help in pursuit of adequate livelihoods, social inclusion, food security, activities of daily routines, establishing social networks and social capital, and access to health and well-being, among others. Short- and long-term needs must be taken into consideration, as the displaced are at serious risk of becoming poorer than before migration, more vulnerable economically, and disintegrated socially. ${ }^{42}$ While social work's suitability and responsibility to address the issue of environmental displacement is clear, there is a need to build capacity to better address these complex relationships in policy development. Application of a social work lens informed by human rights and social justice assists in understanding the personal impacts of environmental displacement, while also locating the issue in a national and international context. Besthorn and Meyer note, "Individual adjustment and coping strategies of the environmentally displaced cannot be considered solely personal issues; they are a matter of international and public concern."43 Global multidisciplinary and multilateral efforts are required to ensure victims of environmentally induced displacement are recognized and supported. This work should be grounded in a human-rights-based approach and should be preventative as well as responsive.

\section{Human Rights}

At the core of the environmentally induced displacement issue are human rights and the lack thereof. The IFRC states, "Individuals have a fundamental right to search for protection through migration, in anticipation of or in response to crisis situations. Fleeing the area is one of the most important protection mechanisms available to individuals and communities to deal with acute and chronic crises such as violent conflict, severe drought and food insecurity, or climate change-related disasters." 44

Human rights are central to social work practice and are reflected in the profession's value in human worth and dignity and expressed in social work's code of ethics at regional, national, and international levels. ${ }^{45}$ The Universal Declaration of Human Rights provides clear guidance in article 13 that "everyone has the right to freedom of movement and residence within the borders of each state." $46 \mathrm{~A}$ rights-based approach encourages greater awareness of the plight of environmentally displaced persons who lack security and rights to a basic standard of living. ${ }^{47}$

Article 12 of the International Covenant on Civil and Political Rights affirms that "everyone lawfully within the territory of a State shall, within that territory, have the right to liberty of movement and freedom to choose his residence." ${ }^{8}$ According to Martin, the ICCPR provides certain exceptions: "The above-mentioned rights shall not be subject to any restrictions except those which are provided by law, are necessary to protect national security, public order (ordre public), public health or morals or the rights and freedoms of others, and are consistent with the other rights recognized in the present Covenant." 49 Numerous challenges remain in the field when human rights are not respected, and there is a need to build capacity in order to better address these violations at the policy level.

\section{Social Work Practices and Approaches}

In this commentary I argue that social workers have a special interest in contributing to international and local policy development and practices that serve to protect and to meet the human rights of environmentally displaced persons 
and groups. In order to effectively address the impacts of environmentally induced displacement, it is necessary to approach the issue in a holistic way by considering the social, economic, and environmental concern pre-migration, during migration, and post-migration. Besthorn and Meyers write, "There would also be meticulous emphasis on not only meeting the immediate needs of environmentally displaced persons but working to change the mechanisms that have created the problem. This means that while professionals are working with environmentally displaced persons directly, they are also expressing their collective voice in the political arenas to advocate for them." 50

From a review of the literature on disasters, it becomes apparent that social exclusion, social injustice, and marginalization that already exist in society are intensified in disaster situations and compounded by environmental degradation caused by destroyed infrastructure, including housing, power, transportation, communication systems, and toxic rubble. ${ }^{51}$ Warner et al. state that people's resilience level and recovery ability from external forces are based on three factors: (1) possession of and/or access to financial assets, (2) the degree of the event and/or destruction, and (3) the employment of strategies that either decrease or increase poverty levels. ${ }^{52}$ For social workers involved with individuals and families that have been displaced, specifically by rapid-onset environmental changes or slow-onset environmental changes, resilience levels and recovery are important, since human well-being is paramount. Social development is concerned with people's well-being. Midgley postulates that economic and social well-being are interlinked: you cannot have one without the other. ${ }^{53}$ Social development and sustainability approaches are being considered in the context of international initiatives such as the Millennium Development Goals and Rio+20 United Nations Conference on Sustainable Development, given the impacts of climate change in today's world. It is imperative that the concerns of environmentally induced displacement be considered in this emergent international policy context and in the development of social protection initiatives.

\section{Discussion of Policies and Principles}

International migration lacks coherent global governance, as sovereign states generally determine their own immigration policies. ${ }^{54}$ Government responses to environmentally induced displacement vary from offering "mobility incentives" to mandatory resettlement programs, with mixed results. ${ }^{55}$ The development of national, regional, and international laws, policies, and organizational responsibilities that contribute to a system of governance require a policy agenda to consider environmentally induced displacement and migration. This situation derives in part from uncertainties about the actual future impacts on the environment, which will likely be exacerbated by climate change. There is a need to address migration more effectively in relation to environmental change, given the lack of policy or institutional responses that are deemed appropriate to these forms of migration. ${ }^{56}$ Several policy responses may be required to address the complexity of migration for environmentally displaced individuals and groups of people that include "internal or cross-border, rapid or slow, forced or voluntary" forms of migration. ${ }^{57}$

Action is needed to help populations affected by environmentally induced migration. Policy-makers, the scientific community, civil society, and various levels of government must seek solutions for those people who are currently migrating and who may be induced to migrate in order to seek safe and sustainable existences. Specifically, I argue that social workers need to build capacity in order to contribute to these debates, particularly in developing social protection initiatives. Environmentally induced migration is a process that can reduce or increase vulnerability, depending upon the context and the multiplicity of factors influencing population movements.

The Nansen Principles serve as a recommendation to guide responses to the urgent and complex challenges raised by displacement in the context of environmental hazards. Specifically, "Responses to climate and environmentally related displacement need to be informed by adequate knowledge and guided by the fundamental principles of humanity, human dignity, human rights and international cooperation."58 The Nansen Principles further explain, "States have a primary duty to protect their populations and give particular attention to the special needs of the people most vulnerable to and most affected by climate change and other environmental hazards, including the displaced, hosting communities and those at risk of displacement. The development of legislation, policies, and institutions as well as the investment of adequate resources is key in this regard." ${ }^{9}$ Finally, "The leadership and engagement of local governments and communities, civil society, and the private sector, are needed to address effectively the challenges posed by climate change" and environmentally induced migration. ${ }^{60}$ In situations where "national capacity is limited, regional frameworks and international cooperation should support action at a national level and contribute to building national capacity, underpinning development plans, preventing displacement, assisting and protecting people and communities affected by such displacement, and finding durable solutions."61 The Hyogo Framework for Action 2005-2015 further offers guiding principles on the need for prevention and resilience to be strengthened at 
all levels, particularly through adequate resources, by international, regional, and local actors. ${ }^{62}$

A critical role in social work is advocacy, and social workers have a responsibility to advocate for marginalized and vulnerable populations that are displaced as the result of environmental changes, whether they are rapid-onset or slow-onset. International social work associations can play a role in the development of policy and strategies that consider social, economic, and environmental factors influencing environmentally induced displacement and migration. This will require building capacity within the profession, drawing upon community development, advocacy, and anti-oppressive approaches. The International Federation of Social Workers is the global federation of national social work organizations in 90 countries, representing over 750,000 social workers. ${ }^{63}$ The International Association of Schools of Social Work (IASSW) is an international community of schools and educators in social work, promoting quality education, training and research in the theory and practice of social work, administration of social services and formulation of social policies. IASSW speaks on behalf of 2,000 schools of social work and 500,000 students. ${ }^{64}$ The International Council on Social Welfare is a global, non-governmental organization that represents tens of thousands of organizations around the world that are actively involved in programs to promote social welfare, social development, and social justice. ${ }^{65}$

\section{Conclusion}

This commentary on social work and environmentally induced migration argues that social work involvement is necessary, as those who are affected most by environmentally induced displacement are vulnerable groups, such as the poor, women, older people, and children. ${ }^{66}$ Not everyone is affected equally by the impacts of environmental changes prompting migration due to natural hazard events linked to climate change and disasters. ${ }^{67}$ It is necessary to understand more clearly what population groups are likely to be affected by environmentally induced displacement and migration, and in what context, in order to design appropriate local interventions that support affected populations. This will likely include social protection initiatives. Environmentally induced migration is affected by the degree to which environmental change affects livelihoods, to which relative wealth (affluence) and asset ownership affects migration, and the severity and extent of environmental change now and in the future. ${ }^{68}$ Environmentally induced migration is an issue of increasing policy relevance, because of inherent uncertainties and the potential magnitude and scope of this phenomenon. Climate-related stressors combined with ecosystem change such as sea-level rise and rapid-onset events such as flooding have the potential to drive migration or prompt national governments to plan for the relocation and resettlement of affected populations. Mechanisms for supporting the settlement and integration of affected migrants is linked to pathways of immigration and migration and require further analysis in terms of benefits, support services, and establishing new livelihoods.

Further research is needed to understand how changing environmental conditions affect individual and group decisions to migrate, and the human and social dimensions of these changes. New definitions and understanding are needed for environmentally induced displaced migrants and people displaced by environmental factors to facilitate identification, measurement, and appropriate policy responses, legal frameworks, and social services. Multidisciplinary perspectives can contribute to increasing awareness and developing knowledge about environmental degradation and climate change impacts on migrants and potential migrants. Countries must understand how environmental processes and the environment affect living standards of their populations.

Policy and legal frameworks need to address environmentally induced displacement and migration experiences of individuals and groups affected by environmental change. Social workers potentially have an active role in promoting and strengthening human rights and social justice, and in empowering affected individuals, families, and communities facing this new reality. Gradual and sudden environmental changes will result in substantial human movements and displacements, and these situations will require timely humanitarian efforts and development interventions to avoid escalating crises.

\section{Notes}

1. David N. Jones and Rory Truell, "The Global Agenda for Social Work and Social Development: A Place to Link Together and Be Effective in a Globalized World," International Social Work 55, no. 4 (2012), doi: $10.1177 / 0020872812440587$.

2. Jon D. Unruh, Maarten S. Krol, and Nurit Kliot, eds., Environmental Change and Its Implications for Population Migration (Dordrecht, Netherlands: Kluwer Academic Publishers, 2004).

3. Ibid.

4. International Association of Schools of Social Work, International Federation of Social Workers, and International Council on Social Welfare, "The Global Agenda: For Social Work and Social Development Commitment to Action" (March 2012), http://www.cswe.org/File.aspx?id=60880.

5. Lena Dominelli, Green Social Work: From Environmental Crises to Environmental Justice (Cambridge: Polity, 2012). 
6. International Association of Schools of Social Work, International Federation of Social Workers, and International Council on Social Welfare, "Global Agenda."

7. Steve Lonergan, "Population Movements and the Environment," Refugee Participation Network (RPN) 18 (January 1995): 4-7; Lonergan, “The Role of Environmental Degradation in Population Displacement," Environmental Change and Security Project Report 4 (Spring 1998): 5-15.

8. Peter Vandergeest, Pablo Idahosa, and Pablo S. Bose, eds., Development's Displacements: Economies, Ecologies, and Cultures at Risk (Vancouver: UBC Press, 2006).

9. Yue Cao, Sean-Shong Hwang, and Jian Xi, "ProjectInduced Displacement, Secondary Stressors, and Health" (University of Alabama at Birmingham, ProQuest, UMI Dissertations Publishing, 2010).

10. Peter Penz, Jay Drydyk, and Pablo S. Bose, Displacement by Development: Ethics, Rights and Responsibilities (Cambridge: Cambridge University Press, 2011).

11. Joseph Kweku Assan and Therese Rosenfeld, "Environmentally Induced Migration, Vulnerability and Human Security: Consensus, Controversies and Conceptual Gaps for Policy Analysis," Journal of International Development 24, no. 8 (2012), doi: 10.1002/jid.2886.

12. Jane McAdam, Climate Change, Forced Migration, and International Law (Oxford Scholarship Online, 2012), doi: 10.1093/acprof:oso/9780199587087.001.0001.

13. Masa Kovic, "Environmental Refugees: Does International Law Fail to Offer Them Legal Protection?" (University of Toronto, ProQuest, UMI Dissertations Publishing, 2008).

14. Susan Martin, "Climate Change, Migration, and Governance," Global Governance 16 (2010), http://www.heinonline .org.ezproxy.tru.ca/HOL/Page?handle=hein.journals/ glogo 16\&id=403\&collection=journals\&index=journals/ glogo\#403.

15. Koko Warner, "UNU-EHS Expert Explains Environmentally Induced Migration on Special Podcast," n.d., http:// www.ehs.unu.edu/article/read/728.

16. Alexander Betts, Survival Migration: Failed Governance and the Crisis of Displacement (Ithaca, NY: Cornell University Press, 2013).

17. Robin Bronen, "Climate-Induced Community Relocations: Creating an Adaptive Governance Framework Based in Human Rights" (University of Alaska Fairbanks, ProQuest, UMI Dissertations Publishing, 2012).

18. David Corlett, Stormy Weather: The Challenge of Climate Change and Displacement (Sydney: University of New South Wales Press, 2008).

19. W. Neil Adger, Fairness in Adaptation to Climate Change (Cambridge, MA: MIT Press, 2006).

20. Corlett, Stormy Weather.

21. Bronen, "Climate-Induced."

22. Ibid.

23. Andrea Milan and Sami Areikat, "Background Paper: Environmentally Induced Migration and Sustainable Development" (January 2011), http://www.webmeets
.com/files/papers/eaere/2011/1107/Environmentally\%20 Induced $\% 20$ Migration $\% 20$ and $\% 20$ Sustainable $\% 20$ Development_Milan_Areikat_Afifi.pdf.

24. Koko Warner, Mohamed Hamza, Anthony Oliver-Smith, Fabrice Renaud, and Alex Julca, "Climate Change, Environmental Degradation and Migration," Natural Hazards 55, no. 3 (2010): 708, doi: 10.1007/s11069-009-9419-7.

25. Martin, "Climate Change," 397.

26. Scott Leckie, Ezekiel Simperingham, and Jordan Bakker, eds., Climate Change and Displacement Reader (New York: Earthscan, 2012).

27. Koko Warner, Tamer Afifi, Olivia Dun, Marc Stal, Sophia Schmidl, and Janos Bogardi, "Human Security, Climate Change and Environmentally Induced Migration" (United Nations University, June 2008), http://www.efmsv2008.org/ file/ELIAMEP+full+report_final-1.pdf.

28. Oli Brown, "Migration and Climate Change," IOM Migration Research Series no. 31 (Geneva: International Organisation for Migration, 2008), http://www.iisd.org/pdf/2008/ migration_climate.pdf.

29. Julia R. Barrett, "Migration Associated with Climate Change: Modern Face of an Ancient Phenomenon," Environmental Health Perspectives 120, no. 5 (2012): A205, doi: 10.1289/ehp.120-a205b.

30. International Federation of Red Cross and Red Crescent Societies, World Disasters Report 2012: Focus on Forced Migration and Displacement (2012), http://www.ifrcmedia .org/assets/pages/wdr2012/resources/1216800-WDR -2012-EN-FULL.pdf.

31. Etienne Piguet, Antoine Pécoud, and Paul de Guchteneire, "Migration and Climate Change: An Overview," Refugee Survey Quarterly 30, no. 3 (2011), doi: 10.1093/rsq/hdr006.

32. Ibid.

33. International Organization for Migration Council, "Discussion Note: Migration and the Environment," MC/INF/288 (2007), 1-2, http://www.iom.int/jahia/webdav/shared/ shared/mainsite/about_iom/en/council/94/MC_INF_288 .pdf.

34. Rafael Reuveny, "Climate Change-Induced Migration and Violent Conflict," Political Geography 26, no. 6 (2007): 656-73.

35. Fred H. Besthorn and Erika E. Meyer, "Displaced Persons: Broadening Social Work's Helping Imperative," Critical Social Work 11, no. 3 (2010), 2013, http://www.uwindsor .ca/criticalsocialwork/environmentally-displaced-persons -broadening-social-work's-helping-imperative.

36. Dominelli, Green Social Work, 106.

37. Ibid.

38. Warner et al., "Human Security.

39. Besthorn and Meyer, "Displaced Persons."

40. Fariyal Ross-Sheriff, "Global Migration and Gender," Affilia 26, no. 3 (2011), doi: 10.1177/0886109911417692.

41. Julie Drolet, Social Protection and Social Development: International Initiatives. (Houten, Netherlands: Springer, 2013). 
42. Martin, "Climate Change."

43. Besthorn and Meyer, "Displaced Persons," 132.

44. International Federation of Red Cross and Red Crescent Societies, World Disasters Report 2012, 67.

45. Lynne Healy, "Exploring the History of Social Work as a Human Rights Profession," International Social Work 51, no. 6 (2008), doi: 10.1177/0020872808095247.

46. Martin, "Climate Change," 402; United Nations General Assembly (GA), Resolution 217 A (III), "Universal Declaration of Human Rights" (10 December 1948), http://www .un.org/en/documents/udhr/.

47. Besthorn and Meyer, "Displaced Persons," 131.

48. Martin "Climate Change," 402; United Nations General Assembly (GA), Resolution 2200 A (XXI), "International Covenant on Civil and Political Rights" (16 December 1966), http://www.ohchr.org/en/professionalinterest/pages /ccpr.aspx.

49. Martin, "Climate Change," 402.

50. Besthorn and Meyer, "Displaced Persons," 132.

51. Lena Dominelli, "Social Work Education for Disaster Relief," in Environmental Social Work, ed. Mel Gray, John Coates, and Tiani Hetherington (New York: Routledge, 2013), 294.

52. Warner et al., "Climate Change."

53. James Midgley, Social Development: The Developmental Perspective in Social Welfare (London: Sage Publications, 1995).

54. Alexander Betts, ed., Global Migration Governance (Oxford: Oxford University Press, 2011).

55. Warner et al., "Human Security."

56. Martin, "Climate Change."

57. Norwegian Refugee Council, "The Nansen Conference: Climate Change and Displacement in the 21st Century," Oslo, Norway, 5-7 June 2011, 14, http://d2530919 .hosted213.servetheworld.no/expose/global/download .asp? $\mathrm{id}=2280 \& \mathrm{fk}=1633 \&$ thumb.

58. Ibid., 5 .

59. Ibid.
60. Ibid.

61. Ibid.

62. Ibid.

63. International Federation of Social Workers, www.ifsw.org.

64. International Association of Schools of Social Work, http:// www.iassw-aiets.org.

65. International Council on Social Welfare, www.icsw.org.

66. Besthorn and Meyer, "Displaced Persons."

67. Julie Drolet, "Climate Change, Food Security and Sustainable Development: A Study on Community-Based Responses and Adaptations in British Columbia, Canada," Community Development (2012), http://dx.doi.org/10 .1080/15575330.2012.729412; Julie Drolet, Grant Larson, Miriam Samuel, and Leon Ginsberg, "Social Work and Disasters: Learning from Diverse Community Narratives in Post-Tsunami Villages in Tamil Nadu, South India," in International Social Development: Social Work Experiences and Perspectives, ed. Tuula Heinonen and Julie Drolet, 122-46. (Winnipeg: Fernwood Publishing, 2012); and Julie Drolet, Miriam Samuel, and Grant Larson, "The Impacts of Natural Disasters in Diverse Communities," International Journal of Diversity in Organizations, Communities and Nations 11, no. 6 (2012): 95-107.

68. Warner et al., "Human Security."

Julie Drolet is associate professor in the Faculty of Social Work at the University of Calgary. The author may be contacted atjdrolet@ucalgary.ca.

Tiffany Sampson is a community-based researcher and graduate of the social work program at Thompson Rivers University.

Deborah Prashanthi Jebaraj is a graduate student at Madras Christian College in Chennai, Tamil Nadu, India.

Laura Richard is a social work student at Thompson Rivers University. 